\title{
Nick: An Unreliable Narrator in The Great Gatsby
}

\author{
Gu Jia \\ Henan Industrial and Trade Vocational College, Zhengzhou, People R China \\ 191760548@qq.com
}

Key words: unreliable narrator, the Great Gatsby, Nick

\begin{abstract}
Based on the theory of unreliable narrator, this paper, by analyzing Nick's function as a narrator, tends to point out that Nick's vision is not identical to Fitzgerald's, for Nick is capable of being an unreliable narrator at moments that are crucial to the development of the story. Indeed, Nick is a flawed character, he is sometimes a confused, misleading, or inaccurate teller of his tale.
\end{abstract}

As the spokesman of "Jazz Age”, Frances Scott Fitzgerald has reflected in many of his works the social upheavals of the "roaring twenties" and the disillusionment of "American dream". His masterpiece The Great Gatsby which is highly praised by George Eliot as "the first step that American fiction has taken since Henry James" (qtd. in Donaldson 268) has raised many critics interests since its publication. It is the fact that many criticisms at home or abroad have touched upon this subject, but most of them are devoted to its theme, the corruption of American dream, the general style, the symbolism used in the novel and etc. Few critics have centered on its unique narrative techniques. Among all the criticisms about it, Robert Emmet Long's The Great Gatsby---the Intricate Art and Matthew J. Bruccoli's New Essays on The Great Gatsby are comparatively the most comprehensive, and yet they are respectively concerned with Fitzgerald's handling of time and space, and the theme of love, money and aspiration that reappears in this novel. The narrative technique is not systematically analyzed, not to mention the special function of Nick as a narrator.

For years, traditional critics have taken it for granted that Nick, as the narrator, is speaking for his author. Furthermore, because something about Nick's “midwesternism” seems deeply personal to Fitzgerald, critics have tended not to distinguish between the narrator and his author. This paper, however, by analyzing Nick's function as a narrator, tends to point out that Nick's vision is not identical to Fitzgerald's, for Nick is capable of being an unreliable narrator at moments that are crucial to the development of the story. Indeed, Nick is a flawed character, he is sometimes a confused, misleading, or inaccurate teller of his tale.

\section{Theories on Unreliable Narrator}

Before the analysis of Nick's unreliability as a narrator, an introduction to the theory of unreliable narrator is necessary.

Wayne C. Booth first made a distinction between reliable narrators and unreliable narrators. “...our terminology for this kind of distance in narrators is almost hopelessly inadequate. For lack of better terms, I have called a narrator reliable when he speaks for or acts in accordance with the norms of the work (which is to say, the implied author's norms), unreliable when he does not" (158). Rimmon-Kenan gives an explanation of the two kinds of narrators: "A reliable narrator is one whose rendering of the story and commentary on it the reader is supposed to take as an authoritative account of the fictional truth. An unreliable narrator on the other hand, is one whose rendering of the story and/or commentary on it the reader has reasons to suspect” (101).

With the term unreliable narrator, Booth's distinction raises a problem for readers: what lies behind the unreliable narrator is the implied author's norms and readers can only gain a full understanding of them after reading through the work. How to pinpoint the norms of the implied 
author is essential for gaining insights into unreliable narrators. Only in this way can the extent to which its narrators are reliable or unreliable be ascertained. "Unreliable narrators thus differ markedly depending on how far and in what direction they depart from their author's norms" (Booth 159). Rimmon-Kenan although explains that the main sources of unreliability are the narrator's limited knowledge, his personal involvement, and his problematic value-scheme(101), does not provide a detailed explanation for readers to identify unreliable narrators in their reading.

Neither of them offers a detailed classification of unreliable narrators.It is James Phelan who optimizes the classification of unreliable narrators. First, Phelan systematically analyzes homodiegetic narration and concludes that homodiegetic narration is closely related to the characters and the narrators on the same axis of the fiction. Therefore, "Any time we have a character-narrator, whether that character is protagonist, witness, or reporter at several removes from the action, the question of reliability is inevitable." (Phelan NR 110) In such a fiction as embracing a charaeter-narrator, the narratorial function and the character function are alternately used by crities to shed light on the (un)reliability of narrators. "Sometimes the reliability of a homodiegetic narrator can fluctuate wildly throughout the progression of a narrative"(111). Fluctuations depend on the variable distance between the narratorial and character functions. When the narratorial functions are operating independently of the eharaeter functions, then the narration will be reliable and authoritative... When the character and narratorial functions are operating interdependently, the narration may be either reliable or unreliable and the degree of the narrator's privilege will vary depending on his or her relation to the action being reported (112). One of the significant contributions made by Phelan is that he systematically analyzes the platform onto which unreliable narrators exist and thrive. He shows that in the homodiegetic narration, character as narrator and narrator as character play a pivotal role in helping critics to find out unreliable narrators.

Second, Phelan uses his rhetorical taxonomy to divide narrator's unreliability into six types: misreporting and underreporting, misreading and underreading, and misevaluating/misregarding and underregarding. All of them involve the unreliable narrators because in Phelan's opinion, "narrators may deviate from the implied author's views in the roles as reporters, as evaluators and as readers or interpreters"(Phelan, “The Lesson of "Weymouth"” 94). Unreliable reporting occurs along the axis of facts/events: unreliable evaluating occurs along the axis of ethics/evaluation: and unreliable reading occurs along the axis of knowledge/perception. Phelan gives the definition of them respectively:

"Misreporting involves unreliability at least on the axis of facts/events.We said 'at least' here beeause misreporting is typically a consequence of the narrator's lack of knowledge or mistaken values."

"Misreading involves unreliability at least on the axis of knowledge/ perception...that misreading is also a sign of a mistaken value system that finds 'unobtrusiveness' to be one of the greatest virtues."

"Misregarding / misevaluating involves unreliability at least on the axis of ethics/ evaluation.”

"Underreporting, which Genette calls paralysis, occurs when the narrator tells us less than he/she knows."

"Under-reading, occurs when the narrator's lack of knowledge, perceptiveness, or sophistication yields an insufficient interpretation of an event, charaeter, or situation."

"Underregarding occurs when a narrator's ethical judgement is moving along the right track but simply does not go far enough" (95-96).

Phelan's taxonomy of unreliability of narrators helps readers to sharpen their perceptions of individual acts of unreliable narration. At the same time, it modifies some reader's established ideas of unreliable narrator, for the reason that “...recognizing these different kinds of unreliability allows us to move away from the common assumption that reliability and unreliability are a binary pair, that once any unreliability is detected all the narration is suspect.”(96) To put it concisely, reliability and unreliability are not absolute and unchangeable, and they are often intermingling in the narration of a novel. From this perspective, it makes possible that the reliability of the unreliable 
narrators contributes a lot to the making of the main characters of novels. The unreliability or reliability of narrators is not unchangeable, more frequently, it is in the process of dynamic changes.” The quality of narrators makes them competent narrators whether they are reliable or not.

\section{Nick as an Unreliable Narrator}

To say Nick is an unreliable narrator and shouldn't be completely believed, is to tamper with accepted notions about the novel's integrity, for some defenders of Nick have argued that "the book makes no sense---if Carraway is repudiated” (Stern 193). Yet the limitations of Nick's character do have narrative consequences, for Nick sometimes sees only part of a meaning that a scene carries, sometimes shifts ground without reason and sometimes even gets judgements from inconclusive evidence.

\section{Description \&Explanation: Readers shouldn't always believe in a narrator}

Even from the very beginning of this novel, the narration invites readers to feel subtle distinctions between description and explanation. This divergence is a characteristic of the novel's narrative style and is repeated variously throughout the story. The narration gives readers two types of impressions: one created through descriptions of places, things, and events, and another created by Nick's responses and reflections. The pattern exhibits itself, for example, in Daisy's story of the butler's nose and her comparison of Nick to an absolute rose.

"I'll tell you a family secret," she whispered enthusiastically. "It's about the butler's nose. Do you want to hear about the butler's nose? ... Well, he wasn't always a butler; he used to be the silver polisher for some people in New York that had a silver service for two hundred people. He had to polish it from morning till night, until finally it began to affect his nose.” (Fitzgerald 14)

... "I love to see you at my table, Nick. You remind me of a---of a rose, an absolute rose. Doesn't he?" She turned to Miss Baker for confirmation: “An absolute rose?” (15)

In the first instance, Daisy's anecdote is trivial and boring, clearly not in accordance with the preparation she makes; in the second her comparison is ridiculous and insincere, intentionally hiding her real preoccupation. But in both cases, Nick is captivated by Daisy's fabulous beauty: "For a moment the last sunshine fell with romantic affection upon her glowing face; her voice compelled me forward breathlessly as I listened" (14); "She was only extemporizing, but a stirring warmth flowed from her, as if her heart was trying to come out to you concealed in one of those breathless, thrilling words” (15). In each example, the narration creates two effects, the first through the structure of incidents--such as the thrown napkin and abrupt departure with which Daisy disposes of her interest in "absolute roses"---and the second through Nick's engagement in her shining face and her beautiful voice. But the two effects judge Daisy oppositely: the former with distance, the latter with engagement. From this we can see that the response Nick emphasizes reveals only one-half the way the scene dramatizes Daisy. To acknowledge such distinctions is already to put the reader at some critical remove from the narrator.

\section{Examples of Nick as a misleading narrator}

An example of Nick's exceeding responses occurs in chapter 4 during his automobile ride with Gatsby to New York (64-69). Fitzgerald's aim in this scene is to create a co-exsisting feeling both active and negative towards Gatsby by deepening our fascination with the mystery of Gatsby. One technique Fitzgerald employs is to preserve the actual truth as a centre in each of Gatsby's falsehoods: he was educated, at least for a few months, at Oxford; he did inherit a "good deal of money" from his spiritual father, Dan Cody, though he was cheated of it; he was a genuine war hero, even if a copy of Sergeant York. Another, more subtle technique is to distance the reader from Carraway's judgment, just as Nick is distanced from Gatsby. Through the episode we can see Nick's cool unreasonable skepticism and his response to Gatsby's telling truth is prejudicial and extreme.

During their journey Fitzgerald calls our attention repeatedly to Nick's filtering lens. We begin with feeling Nick's "disappointment” that Gatsby "had little to say" and his dismissal of Gastby as "simply the proprietor of an elaborate road-house next door"(64). Yet juxtaposed against this wry boredom is the promise of surprise: "And then came that disconcerting ride" (65). Thus, Fitzgerald 
sets the drama of the scene in the development of Nick's change of response. Nick rapidly demonstrates a series of judicious responses: his strained sensitivity at Gatsby's story, “A little overwhelmed, I began the generalized evasions which that question deserves" (65); his fine ear for the false note as Gatsby stumbles, or chokes, over "educated at Oxford. ... And with this doubt his whole statement fell to pieces, and I wondered if there wasn't something a little sinister about him, after all” (65); and his discreet confirming of his own instincts as he asks Gatsby in what part of the Middle West he grew up and is answered "San Francisco. "Nick's power of excellent assessment is in full display.

Carraway's vision of Gatsby is sometimes sarcastic and extreme. When Gatsby recalls the "sudden extinction" of his clan, Nick responds, "For a moment I suspected that he was pulling my leg, but a glance at him convinced me otherwise" (66). Nick momentarily suspects Gatsby of an irony, though Nick's glance leaves unsettled whether he thinks Gatsby means it or not. Gatsby's next image of himself, as a young, sad rajah in the capitals of Europe, tickles Nick with literary hilarity: "With an effort I managed to restrain my incredulous laughter. The very phrases were worn so threadbare that they evoked no image except that of a turbaned 'character' leaking sawdust at every pore as he pursued a tiger through the Bois de Boulogne” (66). Nick reacts in the full possession of his worldliness, distancing the reader from him as he satirizes Gatsby's tale as an incongruent cliches.

Influenced by the absurdity of the "sawdust romance", Nick dismisses Gatsby's war reminiscence: “it was like skimming hastily through a dozen magazines”(67). But Carraway misjudges. Gatsby's tale is not completely incredible in context: unlike the leaking rajah, its subject is realistic, and the whole story is internally consistent. It is later confirmed by Nick himself in subsequent narrative when he summarizes Gatsby's career: "He did extraordinarily well in the war. He was a captain before he went to the front, and following the Argonne battles he got his majority and the command of the divisional machine-guns" (150).

Yet Carraway's judgement on Gatsby does creat a "disconcerting”(65) effect. As Gatsby shows him the medal from Montenegro, Nick begins to surrender: "To my astonishment, the thing had an authentic look"(67). The Oxford picture completes the reversal of his opinion: "Then it was all true. I saw the skins of tigers flaming in his palace on the Grand Canal; I saw him opening a chest of rubies to ease, with their crimson-lighted depths, the gnawings of his broken heart” (67). Nick's conversion is so odd that one may find a hint of irony in it if carefully examined. Nick has made no compensation for the misunderstanding of Gatsby. In fact, he is totally defeated by his own "astonishment” and by Gatsby’s "satisfaction" as he "pockets up his trophies”. Carraway betrays his susceptibility, much like that of which he accuses Gatsby, not only to romance but also to the fantasies of "a dozen magazines."

The climax incident follows. When Gatsby shows a "white card from his wallet" to the motorcycle policeman, who immediately apologizes for having stopped him, Nick asks, "What was that?...The picture of Oxford?”(68). Nick's question is commonly considered sarcastic , though an intentional naivete is possible as well. Yet if Nick is now taking rhetorical revenge, are we to understand his vision of the Grand Canal as sarcastic, too? Or has Nick simply switched to his rationalist mode? If sarcastic, then Nick will undergo yet another great change, since the journey ends in an affirmation of fairyland, "the city rising up across the river in white heaps and sugar lumps,” where "Even Gatsby could happen, without any particular wonder” (69).

\section{Conclusion}

From the above we can see Nick’s judgment of Gatsby is sometimes exaggerated, unstable, and finally self-compromising. The key to Nick's response, of course, is his admission that his "incredulity was submerged in fascination" (67). Whatever degree Gatsby has won Nick, he has won him not by an appeal to evidence but by an appeal to imagination. Because of his impressionability, Nick always grasps a certain image and decks it out with his own imagination. Thus fascination breeds credulity. By the way which Fitzgerald shows Carraway's increasingly convinced of Gatsby, he simultaneously moves the reader as well. Because we diverge from 
Nick--sometimes hesitating at his reactions, sometimes moving beyond them--we feel a firmer objectivity. Nick's unreliablity then, becomes value in the reader's portrait of Gatsby, making him powerful and plausible. Thanks to the distance Fitzgerald establishes between Nick and his reader, even “Gatsby can happen here, without any particular wonder.”(69)

\section{References}

[1] Booth, Wayne C. The Rhetoric of Fiction. Middlesex: Penguin Books Ltd. 1983

[2] Bruccoli, Matthew J. ed. New Essays on The Great Gatsby. Beijing: Beijing U. P. 2007.

[3] Donaldson, Scott. Critical Essays on F.S.Fitzgerald’s The Great Gatsby. Boston: G.K.Hall, 1984.

[4] Fitzgerald, F. Scott. The Great Gatsby. New York: Scribner. 1925

[5] Long, Robert Emmet, The Achieving of The Great Gatsby. London: AssociatedUniversity Press, 1979.

[6] Phelan, James.and Martin, Mary Particia. “The Lesson of 'Weymouth': Homodiegesis, Unreliability, Ethics and The Remains of the Day”. In Herman, David. ed. Narratolologies. Ohio:The Ohio State U.P. p.88-109. 1999

[7] ---Narrative as Rhetoric:Technique, Audiences, Ethics, Ideology. Ohio: The Ohio State U.P. 1996

[8] Rimmon-Kenam, Shlomith. Narrative Fiction: Contemporary Poerics. New York: Routledge. 1989.

[9] Stern, Milton R. The Golden Moment: The Novels of F. Scott Fitzgerald. Boston: Ywayne, 1999. 